\title{
An Overview of Feminism in the Victorian Period [1832-1901]

\author{
Ignatius Nsaidzedze
}

Department of English, Faculty of Arts, The University of Buea, P O BOX 63, South West Region, Cameroon wingroran2002@yahoo.co.uk

Abstract: This paper examines the concept of the "New-Woman" in Victorian literature in all genres written by men and women.The "New-Woman" was also referred to at this time as the "Woman Question".In this paper the "New- Woman", the "Woman Question" and feminism are interchangeable. This write-up handles four issues: the problem faced by the Victorian woman, events, legislation and publications crucial to Victorian feminism, Queen Victorian and feminism and lastly the Victorian writer and the "Woman Question".The Victorian writer wrote essays, novels, plays and poems.Using the feminist critical theory, the paper argues that the predominant theme in Victorian literature was the presentation of the "New- Woman".The paper reveals that the "Woman Question" was so preoccupying that no writer could avoid it during the Victorian period and that feminism really or essentially started during the Victorian period when women were given or got remarkable improvements in their lives.

Keywords: Victorian, feminism, "New-Woman", the "Woman Question", conservative, liberal, radical. INTRODUCTION

In this paper we are going to discuss the problems of the Victorian woman, events, legislation and publications crucial to Victorian feminism, Queen Victoria and feminism and lastly the Victorian writer and feminism or the "New-woman" (The "New-Woman" in the plays, the "New-Woman" in novels, the "New-Woman" in essays or treatises and the "New-Woman" in poetry). The purpose of this article is to show that feminism or the Woman Question was the preoccupation of many Victorian writers.

\section{The Problems Of The Victorian Woman}

During the Victorian era, women had principally two grievances : the vote and property rights. The other problems concerned the law, separate spheres, sex and marriage, economy, prostitution, middleclass women and intelligence.

From a legal point of view, women were incompetent and irresponsible. William Blackstone, an eighteenth century English jurist said that in the eyes of the law husband and wife were one, and that one person was the husband. A married woman was entitled to no legal recourse in any matter, unless it was sponsored and endorsed by her husband. Helpless in the eyes of civil authority, the married woman was in the same category with criminals and lunatics. In short, the Victorian woman was her husband's chattel. She was completely dependent upon him and subject to him. She had no right to sue for divorce or to take custody of her children should the couple separate. She could not make a will or keep her earnings. Upon marriage, the Victorian brides relinquished all rights to property and personal wealth to their husbands.

It was during the Victorian period that the concept of separate spheres for men and women started. These spheres were the public for men and the private or home for women. The woman had her area of expertise which was the home where she was the mother, the homemaker and a devoted domestic. This philosophy of the separation of spheres for men and women was determined by gender. Men were competitive, assertive and materialistic while women were pious, pure, gentle and sacrificing. As Elizabeth Lee points out in "Victorian 
Theories of Sex and Sexuality", there were two human natures corresponding to the masculine and the feminine because of this principle of separate spheres. There was an anabolic nature which nurtured energy versus a katabolic nature which released energy corresponding to feminine and masculine natures or temperaments respectively. These two words are scientific words which we see in biochemistry and biology. Anabolism means the building up or synthesis and catabolism means disintegration or breaking down. Women through these imagery/metaphors are builders while the Victorian men are destroyers.

As we have said above, one stereotype image of women was that they were pure and pious. This is a stereotype which is a positive one. This image of the woman as pure and pious led to the concept of the angel in the house which reminds us of the famous poem of this era : "The Angel in the House" by Coventry Patmore. This image although a stereotype, is a positive one and marked a shift from the image of the woman portrayed in the medieval period influenced by the book of Genesis in the Bible which portrayed or represented a woman as an agent of the devil.

The question may be asked : why were women portrayed as pure, pious and even as angels in the Victorian era? There are four reasons. The first reason was because of the "disappearance of God" in the Victorian period prompted by the advances of science in the name of Darwinism. With the "disappearance of God", theological imagery was shifted from the sacred onto the secular figure of the woman. Secondly, the Victorian experienced evil outside the home. Women at home were either, angelic or regalic - angel or queen. Thirdly Auerbach observed that it was only in the nineteenth century that painters began regularly to portray angels as females. This maybe because of the activities of feminists or the presence of the figure of Queen Victoria. Lastly Auerbach says that the depiction of women as angels was worked out from a tradition that went back at least as far as the German poet and novelist Goethe whose Faust in Faust (1808/1832) is redeemed by the "eternal feminine" (das Ewige webliche) which draws man's mind to higher things. Such thinkers employed a rhetoric drawn from religion to characterize the good mother as a kind of virginal angel. A problem arises only when a writer presents a woman full of contradiction : she is an angel and at the same time a monster, a virgin and whore.

Another factor that impinged on the Victorian woman's rights was sexual abuse. She was a victim of sexual violence or spousal rape. Michael Hale, who was Chief Justice in England during the seventeenth century said a husband could not be guilty of raping his wife "for by their mutual matrimonial consent and contract the wife had given up herself in this kind unto the husband which she cannot retract. The Victorian woman had no right to her own body, as she was not permitted to refuse conjugal duties. Sexual relations within Victorian marriage were unilaterally based on men and male needs. Neither a woman's desire, nor her consent was sought. The sexually abused wife was without security. She relinquished all rights to her body at the marriage alter.

As early as 1600 , jurists made it clear that husbands were entitled to the privileges of marriage. Auguste Debay constructed a regimented schedule for marital sexual relations. A young husband was reasonable if he exercised his rights four times a week and gradually limited his rights with age. She was even believed to be asexual.The Victorian marriage was a patriarchal authoritarian institution wherein the husband was family protector and representative. However, he who was expected to protect, often became the abuser in the bedroom.

Generally Victorian morals disdained sex. Men were advised to limit sexual activity in order to maintain their strength. Women were labelled as frigid for their lack of sexual appetite. It should be noted that the first spousal rape law in the United States was passed in 1979 but was often considered as a misdemeanour.

Victorian women were also deprived of property rights. They wanted to handle their own property instead of being exclusively dependent upon the wishes of their husbands, agitation which culminated successfully in the passing of the Married Woman's Property Acts (1870 - 1908). Most women were seamstresses in the 1840s - "Slaves of the Needle". Domestic service was also "the muted and forgotten" occupation where they spent eighty hours a week as opposed to female factory workers who spent fifty-six hours a week. The problem of the reduction of the factory and mine workers was solved when the women argued that they were comparatively 
frail physically. They did not use the argument that the two were equals. These sixteen hours a day were reduced to ten and a half hours for women and children. Women also worked as milliners and straw-plaiters. The Victorian working women made up $80 \%$ of the population. One out of three women was doomed to spinsterhood. Women both single and married regularly engaged in paid work because the wages of many semi-skilled and unskilled male workers were so low or so uncertain that they would not support a family unless supplemented by the earnings of wives and children.

Another problem of the Victorian woman which was also economic was the problem of prostitution and middleclass women. Bad working conditions and underemployment pushed thousands of women into prostitution which became increasingly professionalized in the nineteenth century.The only occupation at which an unmarried middle class woman could earn a living and maintain some claim to gentility was that of governess. The problem of this job was that the governess could expect no security of employment.She had minimal wages and an ambiguous status which was somewhere between the servant and the family member and which confined and isolated her within the household. It is believed that it was because of the precariousness of the unmarried middle-class woman's status as a governess in Victorian England that the governess novel became such a popular genre through which to explore a woman's role in society. Two famous examples of the governess novels are Jane Eyre and Vanity Fair.

Intellectually, the Victorians believed that man's brain was larger than that of a woman. The woman's brain was $2 \mathrm{lbs}$ (pounds), 11025 ounces (oz) quite inferior to the man's which was $3 \frac{1}{2} \mathrm{lbs}$ (pounds). This meant that men were more intelligent than women and could go further in education because their brains could contain much. Women were therefore meant for the home. It therefore followed or meant that if a woman tried to cultivate her intellect beyond the drawing room accomplishments, she was violating the order of nature and of religious tradition. This claim of men having superior brains to women was supported by scientists like $\mathrm{Mr}$ Darwin. Woman was valued for those qualities which were considered as characteristic of her sex : tenderness, unworldliness, innocence, domestic affection and submissiveness

\section{Events, Legislation and Publications Crucial To Victorian Feminism}

Because of the above problems faced by the Victorian woman, solutions had to be sought. These solutions were in the form of events, legislations and the publication of some essays and novels. These events, legislation and publications can be classified into four domains : publications of novels and essays, publications, events and legislation talking about the importance of education to women, publications, events and legislation talking about the problems of women and lastly the publications, events and legislation talking about the procuration of women's rights (vote, property, child custody, work). It should be noted that some of these events, legislations and publications came before the Victorian period but one thing is clear that it was during the Victorian period that the fight for women's rights began.

The publication of the following literary works were very important in Victorian feminism. In 1845 Margaret Fuller published Woman in the Nineteenth Century which was a major inspiration of American feminist movement. In 1847 Charlotte Brontë published Jane Eyre which was the first Victorian feminist novel and in 1857 Elizabeth Barrett Browning published Aurora Leigh, the first and most feminist of all Victorian poems. In 1855 George Eliot wrote an essay "Margaret Fuller and Mary Wollstonecraft" in which she compared these two harbingers of literary feminism. The most important essay of the Victorian period which spurred Victorian feminism was the publication of John Stuart Mill's "On the Subjection of Women".

A number of Victorian events, legislation and publications have stressed the importance of education to women. In 1848 there was the founding of the Queen's College in London for those who intended to teach especially for women. In 1849 Bedford College was founded only for women. Bessie Parkes wrote and published "The Remarks on the Education of Girls" and in the same year 1856 Emily Shirreff published Intellectual Education and its Influence on the_Character and Happiness of Women. In 1963, Mrs Bathsua Martin wrote "An Essay to American Research Journal of English and Literature

Page 3 
An Overview of Feminism in the Victorian Period [1832-1901]

Revive the Ancient Education of Gentlewomen in Religion, Manners, Arts and Tongues". The Higher_Education of Women was published in 1866 by Emily Davies. Josephine Butler in 1868 wrote The Education and Employment of Women. In 1869 the first Women's College at Cambridge called Girton College was founded. Lastly in 1870 there was the passing of Education Act which gave women the right to serve on School Boards.

There were also events, legislation and publications x-raying some problems of the Victorian woman. In 1801 the census revealed that women outnumbered men. This meant that many women were to remain spinsters or maids for the rest of their lives. In 1846 Anna Jameson wrote "Woman's Mission", "Woman's Position" and "On the Relative Social Position of Mothers and Governesses". In 1857 there was the passing of the Matrimonial Causes Act which stated that a man may divorce his wife for adultery whereas the wife must prove adultery aggravated by cruelty or desertion. 1864, 1866 and 1869 witnessed the Contagious Diseases Act. According to this act, women living in certain garrison towns were liable to be declared prostitutes and forcibly examined for venereal diseases. Finally in 1870, there was the formation of the Ladies National Association for the Repeal of Contagious Diseases Act founded by Josephine Butler. This discrimination (segregation) against women had to come to an end.

During the Victorian period some events, legislation and publications highlighted the procuration of women's rights, that is, the right to vote,to own property, to child custody and work. In 1847 and 1850 there was the passing of the Factory Acts where women and children were restricted to ten and a half hours a day. In 1848 there was the famous and historic Seneca Falls Convention ${ }^{1}$ in the United States which officially started the movement for women's rights. The first National Women's Rights Convention took place in Worchester, Massachusetts in 1850. In 1851, Harriet Taylor, the wife of J. S. Mill wrote "The Enfranchisement of Women" and the women's suffrage petition was presented to the House of Lord by her husband J. S. Mill. In 1852 the judge ruled that a man may not force his wife to live with him. 1854 saw the publication of $A$ Brief Summary in Plain Language of the Most Important Laws Concerning_Women. Caroline Frances Corwallis wrote "The Property of Married Women" in 1856. 1857 saw the coming into existence of the Association for the Promotion of the Employment of Women established and the Matrimonial Causes Act which stipulated that a legally separated wife was given the right to keep what she earned. 1859 saw the birth of the Society for Promoting the Employment of Women. In 1863 Barbara Bodichon published "Of Those who are_the Property of Others, and the Great Power that Holds Others as Property" and in 1866 she wrote "Reasons for the Enfranchisement of Women". In 1869 there was the extension of municipal franchise to women rate payers and the foundation of the American Woman Suffrage Association $^{2} .1870$ saw the first Married Woman's Property Act. The culmination of this was in 1918 when the Voting Act was passed which enfranchised all men over twenty-one and all women over thirty. Here again there was discrimination. All men could vote at twenty-one and all women at thirty. The coronation was in 1928 with the passing of the Equal Franchise Act which gave equal voting rights for both men and women.

Many of the historical changes that characterized the Victorian period motivated discussion and argument about the nature and role of women - what the Victorians called "The Woman Question". The extension of the franchise by the Reform Bills of 1832 and 1867 stimulated discussion of women's political rights. Although women in England did not get the vote until 1918, petition to parliament advocating women's suffrage were introduced as early as the 1840 s.

The champion of the fight for women's suffrage in England was Barbara Leigh Smith Bodichon. She was a rich woman and got married to a French man (Bodichon) who worked in Algeria. She organized herself, spent half a year in Algeria and half a year in England. On her identity card was written "Artist" as her profession, a thing unheard of. In England, she had predecessors. For example, Anne Knight (1786-1862) had founded a Female Political Association in 1847 to demand votes for women and petitioned parliament.Barbara purchased The English Woman's Journal and was able to disseminate her ideas more widely. In 1866 she had drafted and promoted a petition for votes for women, thus sowing the seeds of a nationwide movement for votes for women. In February 1918 female householders aged over thirty were granted the vote, sixty-two years after Barbara Leigh Smith Bodichon's petition. 
Harriet Taylor in 1851 also argued for women's suffrage in the Westminster Review, a paper edited by her husband J. S. Mill. John Stuart Mill it has been suggested became a feminist because of the influence of his wife Harriet Taylor which were often published in his paper. Robert Browning also became a feminist through the influence of his feminist and liberal wife Elizabeth Barrett Browning.

Barbara's priority was to tackle women's non-existence within marriage. When a woman married, everything she owned, inherited or earned belonged solely to her husband to dispose of as he wished. This arrangement was long standing and was rarely questioned. Barbara was complemented by Caroline Norton who joined forces with her and promoted the Matrimonial Causes Act of 1857 which called for alimony payments for women separated from their spouses as well as the recovery of married women's rights to enter contracts, participate in litigation and inherit or bequeath property.

In 1873 Caroline Norton secured the passage of the Infants and Child Custody Bill which prevented women from being unjustly deprived of their children by their husbands. Ironically, Queen Victoria considered such legislation as an abomination.She was very conservative and did not want anything revolutionary or radical during her time. The children in the Victorian era as before belonged to the father.

The Liberal Party seemed a friend to the women's movement until it had the power of office. The Labour Party was sympathetic but nowhere would a party commit itself (Millet 82). As M. H. Abrams et al say, it was evident that Victorian women had many problems and no vote. This does not mean that these women were powerless during this era. They played important roles in shaping the life of the age : "De jure, they seemed powerless dependent ; de facto they often wielded a great deal of power. M. H. Abrams et al add "Although a Victorian grand-mother was unable to vote, she might exert a much more decisive influence on events than her husband did in exercising his ballots" (941). The vote was very important but it was not an end in itself. It was just the beginning in the feminist movement or struggle. To Buckley if the Victorians emancipated women from age old bondage, they also robbed them of a vital place in society (4). Buckley makes the above statement because as we have shown at the beginning of this paper, Victorian women had problems, some of these problems were solved by the Victorian philosophy of separate spheres for men and women which "robbed" the Victorian woman of her place, that is, her opportunity to participate in the public sphere. Although she was denied access to the public sphere, when we compare her to the woman of the past, we notice that much had been done for the Victorian woman. This was just the beginning of the amelioration of the condition of the woman which has achieved near perfection in our own century.

\section{QUEEN ViCTORIA AND FEMINISM}

Queen Victoria during her reign was the queen of Great Britain (the United Kingdom and Ireland) as well as Empress of India. In the minds of many, she personified the spirit of the nineteenth century England. She was a mother of nine children who got married to many countries in Europe like Russia, Spain, Germany and established a strong link between England and Europe.When Napoleon was involved with the affairs of Europe, she continued to isolate England and develop her into the first modern industrial state. She had stored money, trained skilled workers and instituted a government that could not interfere with business relations. The result was that it enabled the middle class to be ambitious owners and inventors of products and factories. During her age, the middle class became very strong. The Reform Bill of 1832 was to give the middle class the right to hold elective office and vote for candidates. In summary, the Victorian age was the age of "prosperity and strict morals".

Victoria was recognized as heir to the throne when George IV died in 1830 and succeeded her uncle, William IV in 1837. When she was crowned, she immediately asserted her independence from her mother, her governess Louise Lehzen and her uncle Leopold (Uglow 558). She was forced to sleep with her mother but after the day of the coronation, she slept in her own room. 
Gilbert and Gubar say that both in England and America the nineteenth century or the Victorian period saw unprecedented changes in the conditions for women's lives, as well as the formation for the first time of a powerful female literary tradition. Women battled for the vote, demanded the right to own property, retained custody of their children after divorce, studied to be physicians and wrote the best sellers. Women both at home and abroad had become so dramatically visible that by the end of the century, the so-called Woman Question - the issue of just what woman's place ought to be in a proper society, had begun to obsess a startling range of thinkers. Gilbert and Gubar think that for three quarters of a century, one woman, Queen Victoria, had occupied a place of extraordinary international significance may have added to the intensity with which such matters were discussed. They conclude by saying that though she was no feminist, the increasing bulking figure of the queen loomed ever larger as the age progressed (170). Queen Victoria from what Gilbert and Gubar have said above can be seen as a kind of inspiration to women during her age.

During her age, the Woman Question was topical:

The Woman Question, as it was called, was concerned with issues of sexual inequality in politics, economic life, education, and social intercourse. In the political sphere it was abundantly evident that women continued to rank as second class citizens. Like millions of working class men, they could not vote or hold office except the highest office of queen (and Victoria was in general an antifeminist) (Abrams et al. 920).

Labelling Queen Victoria as "no feminist" as Gilbert and Gubar did or "anti-feminist" as M. H. Abrams et al have done above, is being too unfair of the term feminist. Some scholars unfortunately use the word to refer to the suffragist movement and this researcher thinks that is what the above mentioned critics have done.The question may be asked, why was she labelled an anti-feminist or "no feminist"? This was because she wrote to Mrs Theodore Martin in the third person and described feminism as this "mad wicked folly of women's rights". Another question may be asked : Why did she describe feminism as this "mad wicked folly of women's rights"? This was because women's rights, that is, the fight for women's rights especially its radical wing, was something which was very revolutionary and she was a conservative. She described herself in politics as a liberal (but this researcher sees her as a conservative) and as such hated anything which was radical. It should be made clear that her monarchy was a model of respectability, self-righteousness, conservatism, and the domestic virtues.

This researcher therefore sees her as a conservative feminist unlike Robert Browning who is seen as a liberal feminist. Liberal feminism is superior to conservative feminism. Feminists are of many trends : radical, conservative, socialist, liberal, Marxist, economist, moral, welfare, psychoanalytical, third world, black, anarchist, phenomenological, post-modernist, Anglo-American and French. There are feminists who choose to focus on the vote, others on education, law or reproductive rights. Queen Victoria who fought for the education of the women in her age cannot be labelled as a non-feminist or no-feminist. She was a woman who like Robert Browning supported women but did not like those changes which were too radical or revolutionary. Browning initially rejected women becoming MPs but later on he changed his idea. We understand this kind of stand. These changes had to come progressively not suddenly. Women who were still fighting to get the right to vote, could not get it in the morning and at noon become deputies in the parliament.

The suffrage movement was not the start and end of feminism. When women got the vote, they still realised that they were opposed sexually, domestically, educationally and otherwise. Queen Victoria encouraged women to pursue education by creating colleges for only girls. To her what was important to women was education at that time. "Believing in education for her sex, she gave support and encouragement to the founding of a college for women in 1847" (Abrams et al 1650).To her the role of the woman was in the domestic sphere. "Many of the queen's female subjects share her assumptions that women's role was to be accepted as divinely willed" (Abrams et al 1651).She encouraged all the women of her age who distinguished themselves like Florence Nightingale. She wrote a letter to her saying that she was very satisfied and added "to make the acquaintance of 
one who has set so bright an example to our sex" (Strachey 143).Lytton Strachey adds Her Majesty's comment "Such a head! I wish we had her at the War Office !" However, according to Strachey "Miss Nightingale was not at the War Office, and for a very simple reason. She was a woman... In her case it is reversed, the qualities of pliancy and sympathy fell to the man; those of command and initiative to the woman" (145 - 150).Florence Nightingale was thus a woman of command and initiative whereas Sidney Herbert who was at the War Office during the Crimean War was pliant and sympathic, a reversal of roles between a man and a woman. This reversal of gender roles is seen in the poetry of Robert Browning.In the Victorian period there was the philosophy of separate spheres or gendered spaces of men and women. The men who were in the public sphere were represented as active or aggressive, and who used the head and the women who belonged to the private sphere (the home) were portrayed as passive, and used the heart. Victorian writers who represented the "New-Woman" usually reverse these roles. Even if they do not reverse these roles, they give those attributes of the male to the female feminist characters in the novel, play or poem.

\section{THE VICTORIAN WRITER AND FEMINISM}

This section of this work discusses feminism in Victorian literature. This will be done in this order : firstly, we will identify the "main feminist trend" in Victorian literature. Secondly, we will try to identify the origin of this "main feminist trend". Thirdly we will look at what might have inspired it. Lastly we will analyse this "main feminist trend" in Victorian literature in the following order : Plays, novels, essays or treatises and poetry.

The main feminist trend in Victorian literature whether written by men or women, be it a play, a novel, an essay or poetry, was the representation of the "New-Woman".The word the "New-Woman" was coined by the novelist Sarah Grand during the Victorian period in 1894. The word feminist was invented by a French Socialist Charles Fourier who imagined a "New-Woman" who would transform her society and also be transformed by that society.The two expressions are synonyms as they were used in the nineteenth century. The differences are that the word feminist was used in the early nineteenth century by a French writer and that the "New-Woman" was used in the late nineteenth century by an English writer. We are not saying here that the word feminist did not exist in English. It did. The word feminist was first used in Britain in 1895, that is one year after the use of the word "New-Woman" in 1894. This was in the journal The Athenaeum and it meant at that time what we mean by it today. The two words are therefore synonyms created at the same time.

In Approaching Literature : Literature and Gender by Lizbeth Goodman she postulates on what might have inspired this concept (221-227) She says the concept might have come up because of the performance of Ibsen's A Doll's House. As we have said earlier, the word was coined by a novelist which means that originally the word was linked only to literature especially the novel, later on drama and as we shall be showing in Browning's poetry. The history of the word "New-Woman" shows that it was used to describe the plays and novels of the Victorian period. In this paper, we want to show that this could not only be limited to these two genres. It was also represented in the treatises / essays and the poetry of that time.

The expression "New-Woman" should not only be linked to literature. If we look at the political, economic and religious conditions of the Victorian period, we may see why the word had to be used. When we talk about a "New-Woman", it means that there must have been an old woman or the woman of the past just like in history they talked about the New World and the Old World referring to America and Europe respectively. We can only compare a "New-Woman" to the woman of the past and not the woman of the future. This is a literal but logical way of reasoning. Therefore the reasons for the use of the word cannot only be literary. Political, economic and religious reasons can also be advanced which warranted the use of the word "New-Woman".

Political wise, the word a "New-Woman" might have come up because of political liberalism, past and present at that time. Liberalism started in the classical period and the modern state like the USA crafts its constitution based on the principles of liberalism. This is seen in the Declaration of Independence with the statement that "All men are created equal, that they are endowed by their creator with certain inalienable rights, that among 
these are life, liberty and the pursuit of happiness" (Fine 933). After the first women's convention took place in 1848, they came up with a document modelled on the Declaration of Independence known as Declaration of Sentiments. In this document, they asserted women's rights to vote, declaring that "All men and women were created equal". They created the journal The Revolution to help in spreading this doctrine. That was in America. In England which is the area of study of this work, the mother of English feminism Mary Wollstonecraft wrote $A$ Vindication of the Rights of Women in 1792 in response to the Declaration of the Rights of Man in 1789 as a result of the influence of liberalism. A Vindication of the Rights of Women is the earliest known feminist treatise.

Economic wise the Industrial Revolution might have made it possible for the use of the word the "New-Woman". It was not only political revolution of the times that provided a basis for change in woman's position, but the Industrial Revolution as well. The explosive growth of the textile industries brought hundreds of thousands of lower-class women into factory jobs. In its disruption of family life and in its similarity to male labour, women's factory work presented an increasing challenge to traditional ideas of women's domestic sphere. The "New-Woman" was one who did not restrict herself only to the domestic sphere but could also go out to the public sphere.

The religious condition of the nineteenth century might have also made it possible for the use of the word the "New-Woman". Firstly, during this period we had many protestant denominations which started to allow women to preach publicly and to become ordained as church ministers unlike the main churches. Secondly and more importantly as we had earlier on pointed out in this work, during this period there was the disappearance of God as a result of the scientific revelations of Darwin and his theory of evolution. As a result of the disappearance of God, divine imagery was shifted to the woman at home. This "New-Woman" was the one to be seen in the domestic sphere, that is, the home. This was well spelt out in Ruskin's treatise "Of Queen's Gardens". In this treatise he says the true nature of the home is that it is a place of peace, the shelter not only from all injury but from all terror, doubt and division. In so far as it is not this, then it is not a home. If the anxieties of the outer life penetrate into it, if the inconsistently minded, unknown, unloved or hostile society of the outer world is allowed to cross its threshold by either the husband or the wife, it ceases to be home. If this happens, then it is only a part of that outer world which we have roofed over and lighted fire in. "But so far as it is a sacred place, a vestal temple, a temple of the hearth watched over by household gods", then it is a real home.

From this philosophy of separate spheres, women were confined to the domestic sphere which was a holy sphere unlike the outside world which was evil. The woman of the past, who was seen as an agent of the devil or evil, in the Victorian period became an agent of God or good. The man who occupied the public sphere of evil was himself evil or the symbol of evil and had to get salvation or go to his god through the woman. This poetic vision of the "New-Woman" is handled in a paper titled "Beauty, Religion and Feminism in Robert Browning's Poetry" by this researcher..

In Victorian drama the "New-Woman" is portrayed in two plays : A Doll's House by Henrik Ibsen (the Norwegian playwright) and Sydney Grundy's play The New Woman. The "New-Women" in Ibsen's play are Nora and Christine Linde as seen in Act 1. In this scene, Nora and Christine have both earned, managed and kept a family together without a man. This makes them "New-Women". To some in the audience these signs of independence seemed positive but for others they were negative because they were unconventional qualities which threatened the stability of a patriarchal society. As a widow, Christine Linde's behaviour can be seen as excusable, but Nora's actions of borrowing money and managing the repayment simply pushes her husband to one side. In a period when votes for women had not been won, Nora's story made contemporary audiences pause to reflect that women could act independently. They could for example cast a vote secretly beyond the knowledge and control of their husbands.

Although Ibsen does not explicitly refer to the "New-Woman" in A Doll's House, the term occurs as the subject and title of a roughly contemporary British play The New Woman by Sydney Grundy. This play appears in the book The New Woman and her Sisters : Feminism and Theatre 1850 - 1814 by Hiv Gardner and Susan Rutherford. 
This play opened the Comedy Theatre on first September 1894. The "New-Woman" of the play's title is Mrs Sylvester a married female with progressive views and conduct. She spends her time with the work of radical sexual philosophy. Three other members of the "New-Woman" sisterhood are regular visitors referred to as Frankenstein of a new gender and badly in need of husband.On the wall of the poster for the performance of the play behind her is a large latchkey in a cabinet. In the margins of the poster is a smouldering cigarette which was the symbol of the "New-Woman" which was instantly recognisable to a large public in 1894. The latchkey and the cigarette were the infamous symbols of her advanced nature.

The "New-Woman" was equally portrayed in Victorian novels. The two important novels are The Odd Woman (1893) by George Gissing and Jane Eyre (1847) by Charlotte Brontë. It is also depicted in two Victorian novels : Jude the Obscure (1896) by Thomas Hardy and Wuthering Heights (1847) by Emily Brontë.

Debra G. Waller in "Angel or Vampire - the Portrayal of Women's Morality and Sensuality in Jane Eyre" says that soon after Jane Eyre was published while J. S. Mill wrote of "A Principle of Perfect Equality" for men and women, Mrs Lynn Linton complained that the girl of the period was excessively forward and independent compared to the simple and genuine girl of the past. By the end of the century, the girl of the period had matured into the "New-Woman", a predatory figure who rejected marriage, advocated contraception and wanted independence through paid work.

As far back as the 1860 s, changing ideas about women had gained sufficient currency that writers began to represent the modern woman as a new type. In 1868 The Saturday Review published an attack on the modern woman by Eliza Lynn Linton called "The Girl of the Period". She was a novelist and a journalist well known for her anti-feminism. Novelist began representing the "New-Woman" as a character type. The term as we said earlier was coined in 1894 by the novelist Sarah Grand and the literary type emerged about the same time. The most famous example is Sue Bridehead in Thomas Hardy"s Jude the Obscure (1896) and Mary Barfoot in George Gissing's The Odd Women (1893). "The Odd Women" means women without husbands. There are five of them in this novel.

Gissing's novel The Odd Women traces the fortunes of five "Odd Women" who must make their own living. One of them Mary Barfoot uses her modest inheritance to train women for works in offices and persuades them of the importance of a women's revolution. Mary Barfoot seeks to teach young women how to lead useful and independent lives, which is the subject of her "Four O'clock Address".In her "Four O'clock Address", she reveals to us that she had training in clerkship. She has capacity for such employment and is looking for girls of like mind to do her best to train them. She is glad that she can show girls the way to a career which her opponents call unwomanly. She knows that she is a troublesome, aggressive and a revolutionary person. What she wants to do away with is that common confusion of the words womanly and womanish. She knows very well that this can only be effected by an armed movement, an invasion by women of the spheres which men have always forbidden women to enter. Browning's character Balaustion does this when she enters the sphere of politics, a domain reserved only for men.This is in a paper titled "Women and Nationalistic Politcs in Robert Browning's Poetry: A Feminist Study of "Balaustion's Adventure" and Aristophanes' Apology".

In Barfoot's opinion, the old types of womanly perfection are no longer helpful to us. We have to ask ourselves what course of training will wake women up, make them conscious of their souls, startle them into healthy activity. She does not care what results, her problem is that women should be made strong, self-reliant and nobly independent.

Men have always said that women should be gentle but to her let women be gentle but at the same time, let them be strong and let them be pure of heart, wise and instructed. Women like her have to set an example to the sleepy of her sex and to do this, they must carry on an active warfare and be invaders. 
To her whether a woman is the equal of man, she neither knows nor cares. But she knows that women are not equal to men in size, in weight, in muscle and "may have less power of brain". These issues to her are not important. What is important to her is that "Enough for us to know that our natural growth has been stunted.

While we agree with her that a woman may not be the equal of man in seize, weight and muscle (but few or some women are), we totally disagree with her when she says a woman "may have less power of brain". Even during the Victorian period, women when given the opportunity to study showed men that they were intellectually equal or even superior to them. Browning had an ocular proof in his wife. Balaustion in Browning's poetry is given the qualities of a woman who is a genius, "gold" and intelligent which were qualities drawn from his wife.

Thomas Hardy wrote Jude the Obscure in 1896. This is Hardy's late Victorian novel which contributed to the breakdown of the puritan code in literature. The "New-Woman" in this novel as we have already said is Sue Bridehead who is the heroine and when she resolves to leave her husband, she just justified her action by citing a passage from J. S. Mill's On Liberty. This means she is leaving the husband because she wants to have her liberty or freedom. The husband might have been very oppressive or domineering towards her.

Wuthering Heights has no outstanding woman who can be described as a "New-Woman", but one of the themes in the novel is talking about women and inheritance in the Victorian period. This novel is a protest against the patrilineal nature of inheritance. A. C. Howard confirms this in the introduction to this novel. He says as English laws of inheritance then stood, a husband was the owner of his wife's property as well as of his own. As Cathy is now the wife of Linton Heathcliff, her father's property passes out to her hands. Young Heathcliff is now desperately ill, but his father refuses to call a doctor, and Linton dies. Heathcliff's plans are now completely fulfilled, for he has forced Linton to make a will leaving his own and Cathy's property to his father, and Heathcliff is at last revenged on all those he regarded as his enemies (XXV - XXVI).

Charlotte Brontë's Jane Eyre is the most feminist of all Victorian novels in which the "New-Woman" is well depicted. It has even been described as a declaration of women's rights. The novel both in its own time and ours has seemed to express woman's rebellion against the limitation of her lot. Margarate Oliphant called it "a wild declaration of the "Rights"'” (Abrams et al 1651). This declaration is true when we look at Chapter Twelve of the novel.In this chapter, the author says that nobody knows how many rebellions besides political rebellions ferment in the masses of life which people earth. Women are supposed to be very calm generally but women feel just as men feel, need exercise for their faculties and a field for their efforts as much as their brothers do. They suffer from too rigid a restraint, too absolute a stagnation, precisely as men would suffer, and it is narrow-minded in their more privileged fellow-creatures to say that they ought to confine themselves to making pudding and knitting stockings to playing on the piano and embroidering bags. It is thoughtless to condemn them, or laugh at them, if they seek to do more or learn more than custom has pronounced necessary for their sex.

Jane who is the heroine and the "New-Woman" in the novel protests against the above injustices as far as women are concerned. Jane longs for wider experience, more excitement and to travel. Some critics think that Charlotte Brontë sells out this idea by having Jane marry and settle to domesticity. Others think that she has not because the message of Jane Eyre is perhaps the search for independence and choice.

Jane is an example of a woman who thinks for herself when faced with a decision. She chooses to follow the course that will maintain her self-respect, however difficult it may be. In practical terms, it was difficult for a woman of her time to achieve true independence. A woman of middle class who did not have money of her own would have to choose between being financially dependent on a husband, living as a dependent governess or the drudgery of teaching in a school. By illustrating this in Jane Eyre, Charlotte Brontë registered a protest that choices were so limited.

American Research Journal of English and Literature

Page 10 
Jane is rescued from this by the money left by her uncle which is enough to make her financially independent. This makes her marriage all right. She does abandon some of her dreams of travel and experience to marry the now disabled Mr Rochester. By this time she can marry him as an equal independent person, or even as the stronger partner in their relationship. At this point in her life her marriage is what she wants. It is as much her own free choice as her earlier decisions.

In 1966 R. B. Martin stated that Jane Eyre was the first major feminist novel "though there is not a hint in the book of any desire for political, legal, educational or even intellectual equality between the sexes". Rather he supports the idea that Jane (Brontë) merely wants recognition that both sexes are similar in "heart and spirit".

In Chapter Three Jane responding to Rochester's callous and indirect proposal asks the following questions - "Do you think I am an automaton? A machine without feeling?... You think wrong - I have much soul as you - and full as much heart..."

In this novel Brontë uses the first person point of view. Despite the fact that Jane Eyre relies upon the moral growth and maturation of both Jane and Rochester, the point of view remains that of Jane alone, and everything is told solely from her point of view. As R. B. Martin explains : one sees all the action and characters through her eyes. Even when she is apparently the passive recipient of information from other characters, we never forget what Jane is feeling. One message we get from this novel is that "love is the pairing of equals".

In the novel there is a double development of a male (Rochester) and female (Jane) leading characters and their eventual marriage. According to R. B. Martin, action moves towards the maturity and self-knowledge of its two central characters. Jane's maturation is of course, the more detailed and central of the two, but Rochester's growth is necessary to complete Miss Brontë's vision of the world. Jane is kept by conscience and the force of example from making gross errors of judgment but Rochester's story is of sin and redemption. The prudent and the imprudent inhabit the same world. The result to him is not divide the novel but to intensify it by showing parallel although differing actions, an effect like that which Shakespeare achieves by doubling his plots, so that, for example, Gloucester's trials, illuminate those of Lear.

The marriage of Jane to Rochester is that of a Christian. Jane waits for the moment that Rochester's wife has died before accepting love and marriage.

The Victorian essayists who handled squarely the concept of the "New-Woman" were curiously men : Walter Besant in his essay The Queen's Reign or The Transformation of_Women's Status Between 1837 and 1897 and John Stuart Mill in his monumental and influential treatise The Subjection of Women. Other secondary essays presenting the "New-Woman" in Victorian literature are written by Sarah Stickney Ellis, George Eliot, Dinah Maria Mulock, Florence Nightingale and Annie Besant.

In The Subjection of Women John Stuart Mill argues that "what is now called the nature of women is eminently an artificial thing - the result of forced repression in some directions, unnatural stimulation in others" (Abrams et al 1903);

In 1859 the same year that Darwin published his book The Origin of Species J. S. Mill published the book On Liberty. "On liberty argues the case for liberty on the grounds of its social utility. These grounds were themselves explained and clarified in his Utilitarianism (1863)" (Castell VIII).

J. S. Mill was very honest when it came to this book. He admitted that his wife helped him a lot. He writes : "To the beloved, and deplored memory of her who was the inspirer, and in part the author, of all that is best in my writings - the friend and wife.... Kate Millet acknowledging Mill's debt to his wife says that Mill composed his essay in collaboration with his step daughter, inspired by his wife, Harriet Taylor. There is no reason to doubt that the knowledge of female psychology which infuses the book required a woman's assistance, but the style and logic are Mill's own. The Subjection of Women is a reasoned and eloquent statement of the actual position of women through history as well as an attack on the conditions of legal bondage, debilitating education, and the stifling ethic of "wifely subjection" within the Victorian period (91). 
The Subjection of Women was a kind of pendant to On Liberty. These two works reveal Mill's intellectual honesty which has been praised by many feminists who have claimed that male writers stole the manuscripts of their wives and published them as theirs. Harriet Taylor's husband died in 1851 and she got married to J. S. Mill who was the editor of Westminster Review. He allowed or gave her a column in this newspaper to write on feminist issues. Under the influence of Harriet Taylor, J. S. Mill became an advocate for the cause of female emancipation, one of several unpopular movements to which he was dedicated.

The book On Liberty has five chapters. It is in the last chapter - Chapter V: Application that he touches on the relationship between husband and wife. He reveals that the almost despotic power of husbands over wives needs not be enlarged upon here because nothing more is needed for the complete removal of the evil than that wives should have the same rights, and should receive the protection of law in the same manner as all other persons, and because on this subject, the defenders of established injustice do not avail themselves of the plea of liberty, but stand forth openly as the champions of power. (Aubrey $106-107$ ).

Throughout human history, as Mill saw it, the role of a husband has always been legally that of a tyrant, and the object of his farseeing essay was to change law and public opinion so that half the human race might be liberated from slavery into the status of individuals. The subjection of women was only one aspect of the tyranny against which he fought. It is an eloquent protest against the manner in which women's freedoms have been subjected to irrational limitations.

It should be noted that the ideas which Mill developed in this essay on the education of women were borrowed on according to a recent publication from Florence Nighttingale. She wrote a book on the education of women which Mill urged her to publish.

John Stuart Mill begins this essay by stating his thesis - the legal subordination of one sex to the other is wrong in itself, and now one of the chief hindrances to human improvement and it ought to be replaced by a principle of perfect equality, admitting no power or privilege in one side, nor disability on the other. He attacks Aristotle who believed in this subordination and praises Plato who did not believe this and says he was probably influenced by the Spartans where women were free and subjected to the same exercises like men and they were the same.

England he says is ruled by a queen and the rule of men over women is not a rule of force. It is accepted voluntarily. Women make no complaint and are consenting parties to it. He says that all men, except the most brutish, desire to have in the woman not a forced slave but a willing one. They have therefore put everything in practice to enslave their minds. The masters of slaves he reiterates rely on fear but men have used the whole force of education to effect their purpose - obedience and submissiveness. All women are brought up from the very opposite to that of men; not self-will and government by self-control, but submission and yielding to the control of others. He compares the relationship between the husband and the wife to that of the lord and his vassal in the Middle Ages.

Walter Besant was a historian, a novelist and a literary critic. In The Queen's Reign or The Transformation of Women's Status Between 1837 and 1987 he set out to show the transformation or the difference between the girl of 1837 and that of 1897 who is her grand daughter.The young lady of 1837 cannot reason on any subject whatever because of her ignorance as she herself would say because she is a woman. In her presence men talk trivialities.The Englishwoman of 1897 is educated as whatever things are taught to the young man are taught to the young woman. If she wants to explore the wickedness of the world she can do so, for it is all in the books. The secrets of nature are not closed to her. She can learn the structure of the body if she wishes. At school, she studies just as the young man studies but harder and with greater concentration.

The Englishwoman of 1897 "has invaded the professions". They have become journalists, in some cases of remarkable ability. They have also invaded other professions like accountants, architects, actuaries, and agents. 
But she cannot study law. Some day she will get over these restrictions. For a long time, she was kept out of medicine. That restriction is now removed. She can and she does practise as a physician or a surgeon, generally the former. She believes that she has shown in this profession as in her university studies that she is an equal not a superior. There is no branch of literature in which women have not distinguished themselves. In music they compose but not greatly. The acting of the best among them is equal to that of any living man.

Women of 1897 do not ask themselves whether they must earn their own bread, or live a life of dependence. It is a necessity. They demand work with personal liberty and independence. They do not care if they combine work and marriage duties. Personal independence is the key note of the situation. Mother no longer attempt the older control over their daughters : they would find it impossible. The girls go off by themselves on their bicycles. They go about as they please.

For the first time in man's history, it is regarded as a right and proper thing to trust a girl as a boy insists upon being trusted. Out of this personal freedom, will come, he says a change in the old feelings of a young man to maiden. He will not see in her a frail tender plant which must be protected from cold winds. She can protect herself perfectly well. He will not see in her any longer a creature of sweet emotions and pure aspirations, coupled with a complete ignorance of the world, because she already knows all that she wants to know. Nor will he see in her a companion whose mind is blank and whose conversation is insipid. Nor, again, will he see in her a housewife whose whole time will be occupied in superintending servants or in making brewing, but confecting things with her own hand.

Sarah Stickney Ellis was a kind of moral feminist in her essay The Women of England: Their Social Duties and Domestic Habits. She came to the conclusion that "the influence of women in counteracting the growing evils of society is about to be more needed than ever" (Abrams et al 1654). This was a woman that Queen Victoria would have supported, whose ideas were not radical or revolutionary. She founded a school for girls which sought to inculcate her theories that feminine education should cultivate what she called "the heart" rather than the intellectual faculties of her pupils. She says to men belongs the potent of consideration of worldly aggrandizement and it is constantly misleading their steps, closing their ears against the voice of conscience. This is an essay which effectively captures the Victorian concept of gender.

George Eliot (Marian Evans) tackled the question of the "New-Woman" squarely only in her essay Margaret Fuller and Mary Wollstonecraft in which she compares two monumental harbingers of feminism in America and England respectively. As Barbara Hardy notes, despites "her generous sympathy with Victorian feminism", George Eliot "played no active part in the movement".

Dinah Maria Mulock in A Woman's Thoughts about Women said that "Man and woman were made for, and not like one another. Only one "right" we have to assert in common with mankind - and that is as much in our hands as theirs - the right of having something to do". The above statement brings out the relationship between man and woman as complements. This cancels the idea of man and woman as equals. But women like men have the right to work. She compares the prospects of Tom, Dick and Harry, who leave school and plunge into life with those girls who like-wise finish their education, come home and stay at home. They have, she laments, "literally nothing to do".

Florence Nightingale wrote Cassandra or Nothing to Do in 1852. She was bored by idle family life and wanted to commit suicide. She called this manuscript her "Family Manuscript". It is a record of her frustrations before she escaped into a professional world where there was "Something to Do". In Cassandra she writes passionalety of the costs for women of having no outlet for their heroic aspirations.

Annie Besant was an essayist who wrote The Political Status of Women (1874), The_Legalisation of Female Slavery in England (1876), The Law of Population (1877), Marriage as it was, as it is, and as it should be : Plea For Reform (1878), "Why I became a Theosophist" (1889), and An Autobiography (1893). Teresa de Ataide Malafaia 
reveals that "In her writings she does take a feminist approach to her topics, on considering gender as culturally constructed ideas and expectations of female and male roles". The pamphlet The Legalisation of Female_Slavery in England was her contribution to the campaign to repeal the Contagious Disease Act which was passed on April 1885. The pamphlet showed her as a form of resistance as she questioned the myth of feminine chastity as well as the duality of Victorian Sexual values which forgot "the nobility of sexual morality on man and woman alike". She included contraceptive information in the new edition on The Law of Population. The Obscene Population Act (1857) aimed at the elimination of pornographic publications was frequently used to prevent the circulation of information on contraception. She was tried with Bradlaugh in London for spreading contraceptive knowledge. During the nineteenth century there was still a great ambivalence concerning contraception. This is the reason why Besant's works were threatening to the apparent Victorian stability.

The "New-Woman" was realistically represented in Victorian poetry by Elizabeth Barrett Browning in her poem Aurora Leigh, Robert Browning in many of his poems and Tennyson in his poem The Princess. Coventry Patmore in his poem "The Angel in the House" also portrayed the "New-Woman".

Christiana Rossetti was a renowned Victorian female poet but who did not handle well the concept of the "NewWoman" in her poetry. She was a Christian and as such disassociated herself from the suffrage movement and thought that women's rights and Christianity were at odds. In her poetry she is seen as a poet speaking from within female limitations. Rossetti presents an internalised female passivity while remaining immune to social pretensions. This means that she wrote about internal problems and not about external human problems like the Woman Question, evolution, industrialism, politics, economy, culture and society. She was writing about her own internal problems or life or strife.

Coventry Patmore wrote "The Angel in the House" (1854-62). This poem reflects the Victorian ideology or philosophy which claimed that the woman had a special nature peculiarly fit for her domestic role. It subscribes to the Victorian concept of the place of a woman being the home of purity and selflessness or "self-renunciation". Protected and enshrined within the home, the woman's role was to create a place of peace where man could take refuge from the difficulties of modern life. The home was a "sacred place, a vestal temple, a temple of the hearth watched over by household Gods.... The "Household Gods" here are women who are seen as angels. Ruskin used the expression "Household Gods", Coventry Patmore used angel as seen in the title of the poem "The Angel in the House".

Such an exalted conception of home placed great pressure on the woman who ran it to be enduringly and incorruptibly good; instinctively and infallibly wise, to be wise not for self-development but for self-renunciation as Ruskin put it (Abrams et al 1904).

It is easy to recognise the oppressive aspects of this ideology. Paradoxically it was used by feminists and antifeminists. It was used only by anti-feminists eager to keep woman in her place but by some feminists as well in justifying the special contribution that woman could make to public life (Abrams et al 1904).

Tennyson's long poem The Princess (1847), with its fantasy of a woman's college from whose precincts all males are excluded was inspired by contemporary discussions of the need for women to obtain an education more advanced than that provided by the popular finishing schools such as Miss Pinkerton's Academy in Thackeray's Vanity Fair. Although by the end of the poem, Princess Ida has repented of her Amazonian scheme, she and the prince look forward to a future in which man will be "more of woman, she of man". "More of woman, she of man" is a liberal perspective by Tennyson to end the conflict or debate on the Woman Question raised in the poem. The other perspectives are radical and conservative. Between radical and conservative, the middle-way is the liberal.

The Princess reflects a climate of opinion that led in 1848 to the establishment of the first women's college in London, an example later recommended by Thomas Henry Huxley ${ }^{4}$, a strong advocate of advanced education 
for women. By the end of Victorian's reign, women could take degrees at twelve university colleges and could study, although not earn a degree at Oxford and Cambridge.

In 1975 James R. Kincaid published Tennyson's Major Poems. Chapter Four is entitled The Princess. To the author of this book, The Princess is a comedy. Princess Ida is much closer to genuine heroism than to humorous amazonism. Throughout the poem Tennyson exercises various rhetorical means to promote our regard for heroism and for its advocate, Princess Ida. The prince's father,the King, who is an anti-feminist argues that women are inferior but useful animals to be hunted , tamed and subdued if all else fails by the misery of childbearing and child-rearing. Princess Ida who is a "New-Woman" never rants. Ida's university is legitimate as is her dedication to learning. Her university does not seek to combat marriage but to make it just a little less like slavery. She is not preparing celibates or man-haters but those who may win, those self-styled the ally of our lords. Whatever she herself may be, her institution is hardly anti-social. She only seeks a readjustment in society, a movement toward balance. Ida herself never speaks of dominance. She hopes to give back to women the individual Edens they have lost. Women who are laughing stocks of time, Ida promises may be conquerors of time and death.

The Princess as we said earlier gives us the various adherents of the Woman Question. There are three : the conservatives represented by the prince's father who thinks that the woman's place is in the home or hearth and that the woman is the heart and the man the head, the radicals represented by the Princess Ida at the beginning of the poem who wants to create a university only for women, and the liberal's position (which is also that of Tennyson) spoken at the end of the poem by the prince and the Princess Ida, a combination of the conservative and the radical perspectives to the Woman Question. The Princess Ida argues that if the parasitic forms which seem to keep women up but drag them down were removed, then a statelier Eden will come back.

In Sexual Politics Kate Millet says Tennyson's premise in the poem is that Ida may study or love, not both. To her the male is thesis, the female antithesis and marriage is the synthesis. As the male has no intention of sharing his university, the female can only set up her own artificial alternate culture, a project of segregated education to the propositions of a totally segregated society.

Ida's almost humble request to be allowed to enter upon the cultural heritage of civilization must be made to seem outrageous and grotesque by Tennyson. Tennyson insists on turning her woman's college into a separatist Amazon fantasy of his own, part mockery and part titillation. This might appear to be mere sarcasm but in fact chivalry did apprehend that women would cease to marry on the terms expected of them when education gave them other choices. That is why The Princess in a curious, otherwise inexplicable manner proceeds to change the subject from education to marriage.

Tennyson is persuaded by the eloquence of Ida's feminism which comes through despite the heavy-handed burlesque under which he tries to drape it. Princess Ida is very exciting. The poet's hero wishes to marry her but he is not prepared to marry an equal. Siege must be laid to tame her into a docile but slightly above - average housewife whose additional accomplishment is a discarded bit of learning. An unpleasant presentiment has occurred to the pact : what would happen to men if women were their intellectual equals? Would they be rejected, no longer served and soothed? Ida's demand for equality in education is obviously cutting too close. In fact it might wreck Victorian marriage (Millet 77).

In this poem, the Victorian doctrine of the separate spheres for men and women is well spelt out. The statement comes from the prince's father who is a male supremacist:

Man for the field and woman for the hearth

Man for sword and for the needle she;

Man with the head, and woman with the heart 
Man to command and woman to obey;

All else confusion (Millet 78).

The king's relegation of woman to heart and hearth reflects a belief that woman's special nature fits her for domestic role as described in Coventry Patmore's poem "The Angel in the House". The irascible old man sees in Princess Ida a likely breeder of warriors, and advises his son to get her.

Man is the hunter, woman is his game.

The sleek and shining creatures of the chase;

We hunt them for the beauty of their skins;

They love us for it and we ride them down (Millet 79).

The imagery in the above verses is that of war, violence and oppression. Man is the oppressor and woman is the oppressed.

Elizabeth Barrett Browning wrote Aurora Leigh. Aurora Leigh is a 350 - page - poem, a novel in blank verse, containing twelve thousand lines and in nine books, longer than Paradise_Lost and it offers a comprehensive treatment of Elizabeth Barrett's complicated feeling about love. "Love relationship is very crucial to feminists". This is the subject of a paper titled "Love and the "New- Woman" in Robert Browning's Poetry. "One of the greatest issues of concern in feminist theory is the role women play in relationship". This is the concern of Laurelyn Douglas in "The Woman Question, the Problem of Love, and Aurora Leigh". The poem Aurora Leigh tells the story of the development of a woman poet largely as the story of her struggle to understand how her life and art can accommodate love. The poem's romantic focus on the subjectivity of the narrator has led to it being called a feminist version of William Wordsworth's autobiographical poem "The Prelude". Aurora Leigh combines a verse buildungsroman (or spiritual epic) like The Prelude, tracing the growth of a woman poet's mind. The poem is autobiographical.

Elizabeth Barrett Browning was an "English poet, political thinker and feminist". In Aurora Leigh, she sets out to attack the degrading education most nineteenth century women received and defended their right to intellectual self-determination. In this poem, she defends a woman's right to intellectual freedom and addresses the concerns of the female artist.

In Book One, the poet-to-be Aurora, born in Italy of an Italian mother and an English father, is orphaned early and brought to England where she is raised and educated by her father's sister, an austere British lady. In this Book One, she reveals memories of her mother and her reactions to her Victorian training in decorum.

In Book Two, Aurora's cousin Romney Leigh, now the head of the family has proposed to her, arguing that it would be better for her to join him in working for social welfare than to continue with her plan to become a poet, since he believes that women can't write effective verse. She refuses, insisting upon her commitment to her chosen vocation.

In Book Five, Aurora now a struggling poet living in London, formulates her artistic beliefs and goals, distinguishing her ideas about poetry from those of her contemporaries.

This poem explores the Woman Question as it was called by contemporaries. In it, she dramatizes the modern woman's severe need for mothers, for that is nurturing political and literary female ancestors. In examining the growth and development of a woman poet, Aurora_Leigh shows that women cripple themselves by internalising patriarchal or androcentric conceptions of themselves. Woolf's idea that a woman writer thinks back through her mothers was borrowed or had been expressed by Elizabeth Barrett Browning. 
In presenting her heroine's path to poetic and personal maturity, Barrett Browning not only explored the Victorian relation between gender and genre but she also created a female literary tradition by alluding to her predecessors. Her work draws upon novels written by women, Charlotte Brontë's Jane Eyre being one major source : the female protagonist's status as an orphan, the figure of a cruel aunt, the proposal by St Rivers, and Rochester's blindness all appear in Aurora Leigh. The second contribution to a female tradition appears in the poem's continual use of a gynocentric, as opposed to androcentric imagery. She substitutes male types with female types from the Old Testament and even goes as far as describing men using female figures.

In "Female Saviors in Victorian Literature" Emily C. Constable writes : "Elizabeth Barrett Browning does not conceal her, feminist views in Aurora Leigh. The heroine, Aurora, constantly demonstrates her independence and speaks her opinions". Amidst a novel - poem filled with such passages as this, the theme of a female leading character who saves a man does not seem out of context. Aurora Leigh, like many other Victorian novels, revolves around a central female character who marries her beloved man at the end of the novel-poem that would otherwise be meaningless and desolate.

Suzane Hader in "The Bildungsroman Genre : Aurora Leigh" says Aurora refuses to accept the role of obedient wife, since it would mean forgoing the intellectual independence needed to develop as an artist but then she must also refute the love of a husband. Although she embraces Marian as the perfect mother, she does not seek to develop those qualities in herself, and instead assumes the masculine role of her provider and protector. Romney is a symbol of Victorian male authority. Romney in turn admits that she can be both a woman and a poet, thus their love is consummated. And as he now is blinded and powerless, he must give up his male pride. She surrenders her artist's power and declares her previous boasting to be foolish.

M. Bernadette Vergar in "Questions of Feminism in Aurora Leigh" says that both Lady Waldemar has her own fortune while Aurora earns her living through her writing, but neither one could be said to represent the great majority of the Victorian women.

In "Victorian Constitution of Gender in Aurora Leigh" Timothy Farrell notes that despite Aurora's assertion of autonomy in Book II and Barrett Browning's fusing of two distinct genres, the ideal woman which Aurora Leigh imagines is similar to that which Dickens imagines. Aurora Leigh shares with Great Expectations the notion that women have the power to remoralize man and to bring him closer to God.

With Aurora Leigh, Barrett Browning revises the Victorian gender construction which roots the virtuous woman firmly in the domestic sphere. Barrett Browning imagines that a woman can have a public existence and still perform her function as moral repository.In revising the Victorian gender paradigm, however, Barrett Browning runs into a difficult problem. How is Aurora going to keep her virtue once she has an existence in the amoral public sphere?

Gelpi notes several places in the text where Barrett Browning depicts Aurora in masculine terms. For instance not only does Aurora share the same last name with Romney, she also resembles him physically. Lady Waldemar writes : "Your droop of eyelid is the same as his". (IX 163). She compares herself to a deer - a stag not a doe. At the beginning of the poem, Aurora uses masculine terms to describe herself in order to preserve her femininity from the amoralness of that sphere. As the poem progresses, Aurora begins to lose her masculine identity and becomes a true woman, that is a feminine woman in both action and spirit. By the novel-poem's end, Aurora seems to have lost all traces of masculinity. She tells Romney that she was wrong in her initial assumption that she could simultaneously be a wife and an artist.

Whereas Barrett Browning does not contain Aurora within the confines of the home, she ultimately has Aurora submit to the bourgeois construction of gender by having her admit that she cannot function as a woman or as an artist independently of her cousin Romney. The fact that she submits to this construction on her own demonstrates the extent to which Victorian women internalised the image of women idealized by their culture. The image of woman as the "Angel in the House", as a moral repository whose function it was to counterbalance the husband's exposure to the amoral world of the market place. 
In "Prisons in Aurora Leigh" Ellen Geroux says "Aurora serves as Barrett Browning's example of the woman confined by society's unjust rules". We see from the beginning of the poem that society challenges Aurora's determination to become a poet and that the challenge weighs so heavily upon her that she risks not pursuing her talent.

We are delighted to know that this poem is still relevant to our modern society. Today, the readers of Elizabeth Barrett Browning's Aurora Leigh - especially the women -are struck by Aurora's admirable independence and strength of character. Such a well-educated and strong - minded heroine seems extraordinary coming from the pages of a nineteenth century Victorian work of literature. Aurora Leigh equally addresses a modern theme - prostitution as portrayed in the "novel - poem" by Marian Erle. She is sold to a bawd in a brothel in France where she is raped. She becomes mad because of this indignity of rape.

\section{CONCLUSION}

In this paper we have discussed the problems which the Victorian women faced and attempts to solve these problems by the parliament through legislative acts,publications by writers of literary works and also by the pro-feminist politics of the Supreme Head or the Crown represented at the time by Queen Elizabeth and lastly we looked at the image of the New-woman in Victorian litereature

\section{NoTES}

1- The Seneca Convention in New York was led by antebellum reformers like Elizabeth Candy Stanton and Lucretia Mott.

2- The suffragist movement in America had two wings : the radical wing led by Stanton and Anthony (NWSA) and the conservative wing led by Lucy Stone (AWSA) - American Women Suffrage Association. The two later on merged to form NAWSA.

3- The English language being androcentric or phallogocentric makes some people think that to solve this, we should use androgyny, bisexuality or hermaphroditism where the male and female go together. But here there is a problem because the male always comes before the female in every androgyny.

4- Thomas Henry Huxley was one of the younger scientists and "ablest popularises of science who described himself as Darwin's “bull-dog”. He told Bishop Wilberfore who came to demolish Darwin's book that "He (Huxley) was not ashamed to have a monkey for his ancestor but he would be ashamed to be connected with a man who used great gifts to obscure the truth" (Abrams et al 1627). At the end the Bishop who came to demolish Darwin was instead demolished by Huxley.

\section{REFERENCES}

Abrams M.H et al. The Norton Anthology of English Literature, Fourth Edition, Volume 2, New York: WW Norton \& Company, 1979

Besant, Walter. From The Queen's Reign (The Transformation of Women's Status Between 1837 and 1897). In The Norton Anthology of English Literature, Fourth Edition, Volume 2, edited Abrams M.H. et al, New York: W.W. Norton \& Company, 1979, 1667 - 1669.

Bowyer, John Wilson \& John Lee Brooks. The Victorian Age: Prose, Poetry and Drama. New York: Appleton-Century-Crofts, 1954 (edited with Introduction, Bibliographies, and Notes)

Brontë, Charlotte. Jane Eyre. ed by Helen Cross. London: Heinemann Education Publishers, 1993

Brontë, Emily. Wuthering Heights. ed A C Ward. London: Longman Group Limited, 1959

Buckley, Jerome H. Goldentree Bibliographies: Victorian Poets and Prose Writers. New York: Appleton-Century-Crofts, 1966 
Chesterton, G.K. Robert Browning. London: MacMillan, 1961

Cohen, J.M. Robert Browning. London: Longmans, Green and Co., Ltd; 1964

Constable, Emily C. "A Contemporary Review of Aurora Leigh" 25 November 2000 at http://landow.stg.brown. edu/victorian/ebb/alreul.html.

"Female Saviors in Victorian Literature" 8 March 2000 at http://landow.stg.brown.edu/victorian/ebb/61a14.html

"The Passion of True Love" 16 March 2000 at http://landow.stg.brown.edu/victorian/brontë/cbrontë/61brnt16.html

Drew, Philip. "Browning and Philosophy" Writers and Their Background (1974): 104-141

"Robert Browning". In British Writers: Volume IV: William Wordsworth to Robert Browning ed. Ian Scott-Kilvert. New York: Charles Scribner's Sons Ltd, 1981, 354-375

Ellis, Sarah Stickney. From The Women of England: The Social Duties and Domestic Habits [Disinterested kindness]. In The Norton Anthology of English Literature, Fourth Edition, Volume 2, edited by Abrams et al, New York: W.W. Norton \& Company, 1979, 1653 - 1661.

Eliot, B. George. Margaret Fuller and Mary Wollstonencraft. In The Norton Anthology of English Literature, Fourth Edition, Volume 2, edited by Abrams M.H. et al, New York: W.W. Norton \& Company, 1979, 1655 - 1661.

Farrell, Timothy."Victorian Constructions of Gender in Aurora Leigh” 8 March 2000 at http://landow.stg.brown. edu/victorian/ebb/farell3.html

Geroux, Ellen. "A Contemporary Review of Aurora Leigh" 25 December 2000 at http://landow.stg.brown.edu/ victorian/ebb/61all.html

"Prisons in Aurora Leigh" 8 March 2000 at http://landow.stg.brown.edu/victorian/ebb/61a16.html

Gilbert, Sandra M. and Susan Gubar. The Norton Anthology of Literature By Women : The Tradition in English. New York: W.W. Norton \& Company, 1985.

Hader, Suzane. “The Bildungsroman Genre: Aurora Leigh” 8 March 2000 at http://landow.stg.brown.edu/ victorian/ebb/br.al.html

Lee, Elizabeth. "Feminist Theory-- An Overview 10 March 2000 at http://landow.stg.brown.edu/victorian/ gender/femtheory.html

"Victorian Theories of Sex and Sexuality" 16 March 2000 at http://landow.stg.brown.edu/victorian/gender/ sextheory.html

"Women in Literature -- A Literary Overview" 10 March 2000 at http://landow.stg.brown.edu/victorian/ gender/womlitov.htm

Macleod, Laura. "Robert “The Obscure” Browning” 24 November 2000 at http://www.incompetech.com/ authors/rbrowning

Mill, John Stuart. On Liberty. New York : Appleton-Centuny-Croffs, Inc 1947 edited by Alburey Castell.

Mill, John Stuart. "The Subjection of Women".: From The Feminist Papers Adams to de Beauvoir edited Alice S.Rossi New York: Columbia Univ. Press, 1973, 196-238.

Millet, Kate. Sexual Politics. New York: Published by Avon (Equinox Books), 1971 (1970 by Kate Millet).

Mullock, Dinah Maria. From A Woman's Thoughts About Women (Something to Do). In The Norton Anthology 
An Overview of Feminism in the Victorian Period [1832-1901]

of English Literature, Fourth Edition, Volume 2, edited by Abrams M.H et al, New York : W.W. Norton \& Company, 1979, 1661 - 1663.

Munich, Adrienne Auslander. "Browning Female Signature" Critical Essays on Robert Orr,Sutherland. "Life and Letters of Robert Browning" 25 July 2001 at http://www.Worldwide.school.org/library/books/hst/ european/LifeandLettersofRobertBrowning/Chap22.html also at ftp://metalab.unc.edu/pub/docs/ books/gutenberg/etext96/Orrbrio.txtBrowning (edited by Mary Ellis Gibson) 1992: 120-138.

Sharp, William. "Life of Robert Browning" 25 Nov. 2000 at http://www.britishliterature.com/authors/Sharp, William_-_life_of_RobertBrowning.txt

Stranchey, Lytton. Eminent Victorians, London: Collins, 1967

Vergara, M Bernadett. "Conflicts of the Woman Poet in Aurora Leigh” 8 March 2000 at http://landow.stg.brown. edu/victorian/ebb/bv6.html.

"Questions of Feminism in Aurora Leigh" 8 March 2000 at http://landow.stg.brown.edu/victorian/ebb/bv4.html

Waller, Debra G. "Angel or Vampire - the Portrayal of Women's Morality and Sensuality in Jane Eyre" 16 March 2000 at http://landow.stg.brown.edu/bronte/cbronte/waller1.html

“Avoiding Dangerous Sexuality in Jane Eyre” 16 March 2000 at http://landow.stg.brown.edu/victorian/bronte/ cbronte/waller4.html

Ward, Sira. \& Waller, A.R. The Cambridge History of English Literature, Vol. XII: The Nineteeth Century: Part Two Chapter III: 49-84: Robert Browning and Elizabeth Barrett Browning. Cambridge: At the University Press, 1961

Citation: Ignatius Nsaidzedze, "An Overview of Feminism in the Victorian Period [1832-1901]" American Research Journal of English and Literature, vol 3, no. 1, 2017, pp. 1-20.

Copyright (c) 2017 Ignatius Nsaidzedze, This is an open access article distributed under the Creative Commons Attribution License, which permits unrestricted use, distribution, and reproduction in any medium, provided the original work is properly cited. 